\title{
Profil Fitokimia dan Aktivitas Antioksidan Beberapa Tumbuhan Genus Artocarpus di Indonesia
}

\author{
Ayu Ina Solichah ${ }^{1,5}$, Khoerul Anwar4, Abdul Rohman² dan Nanang Fakhrudin ${ }^{3^{*}}$ \\ 1Program Magister Ilmu Farmasi, Fakultas Farmasi, Universitas Gadjah Mada, Sekip Utara, Yogyakarta, \\ Indonesia \\ ${ }^{2}$ Institute for Halal Industry and System (IHIS), Universitas Gadjah Mada, Yogyakarta, Indonesia \\ ${ }^{3}$ Departemen Biologi Farmasi, Fakultas Farmasi, Universitas Gadjah Mada, Sekip Utara, Yogyakarta, Indonesia \\ ${ }^{4}$ Program Studi Farmasi, Fakultas MIPA, Universitas Lambung Mangkurat, Banjarmasin, Kalimantan Selatan \\ ${ }^{5}$ Program Studi DIII Farmasi, Sekolah Tinggi Ilmu Farmasi Nusaputera Semarang, Semarang, Jawa Tengah, \\ Indonesia \\ *Corresponding author: Nanang Fakhrudin I Email: nanangf@ugm.ac.id
}

Received: 23 June 2021; Revised: 22 July 2021; Accepted: 23 July 2021; Published: 26 July 2021

\begin{abstract}
Abstrak: Artocarpus merupakan tumbuhan genus utama keluarga Moraceae dengan jumlah spesies hampir 1.300. Beberapa spesies genus tersebut dimanfaatkan sebagai makanan dan obat tradisional di Asia Tenggara, termasuk Indonesia. Jenis yang banyak tumbuh di Indonesia yaitu Artocarpus altilis (sukun), Artocarpus camansi (kluwih), Artocarpus heterophyllus (nangka), Artocarpus integer (cempedak), dan Artocarpus odoratissimus (tarap). Review ini bertujuan untuk mengkaji perbedaan antar spesies, profil fitokimia, dan aktivitas sebagai antioksidan dari kelima tumbuhan tersebut. Narrative review ini ditulis berdasarkan penelusuran literatur berupa publikasi artikel penelitian yang ada di basis data Google Scholar, PubMed, Scopus dan Science Direct. Selain itu digunakan sumber pustaka lain berupa buku dan naskah tugas akhir untuk memperkaya isi artikel. Hasil kajian literatur terhadap 5 tumbuhan tersebut menunjukkan bahwa secara morfologi tumbuhan genus artocarpus relatif mudah dibedakan kecuali sukun dan kluwih yang memiliki kemiripan tinggi, terutama daunnya. Profil fitokimianya memiliki kesamaan dengan kandungan utama berupa senyawa fenolik termasuk flavonoid, stilbenoid, arilbenzofuron, dan neolignan yang tersebar pada bagian daun, buah, bunga, dan kulit. Keunikan dapat ditemui dengan adanya senyawa golongan flavonoid terprenilasi dan tergeranilasi seperti 2-geranil2',3,4,4'-tetrahidroksi dihidrokalkon. Senyawa-senyawa fenolik tersebut mempunyai kemampuan sebagai antioksidan yang relatif kuat pada beberapa model uji dan berpotensi untuk dikembangkan sebagai agen antioksidan atau kandidat obat terutama untuk penyakit yang melibatkan mekanisme radikal bebas dalam patofisiologinya.
\end{abstract}

Keywords: Sukun; Kluwih; Cempedak; Tarap; Moraceae; Fenolik

\section{PENDAHULUAN}

Tumbuhan merupakan salah satu sumber senyawa bioaktif yang berpotensi sebagai obat. Indonesia merupakan negara mega biodiversitas dengan tumbuhan obat yang melimpah dan berpotensi untuk dikembangkan sebagai produk obat tradisional. Saat ini pemanfaatan bahan alam untuk pengobatan dan pencegahan berbagai penyakit terus diminati. Penggunaan tumbuhan untuk menyembuhkan berbagai macam penyakit, memiliki sejarah yang panjang. Beberapa bagian tumbuhan seperti daun, batang, kulit kayu, dan akar dapat digunakan untuk mencegah, 
menghilangkan gejala atau mengembalikan kelainan menjadi normal [1,2]. Sejak zaman dahulu manusia menggunakan tumbuhan dan bahan alami lainnya sebagai obat untuk mengurangi rasa sakit, menyembuhkan, dan mencegah suatu penyakit. Keluarga (family) tumbuhan yang anggotanya relatif besar dan berpotensi sebagai sumber bahan bioaktif adalah Moraceae. Family ini terdiri dari 60 genus yang mencakup lebih dari 1.300 spesies [3]. Menurut referensi, ada 23 spesies tumbuhan genus Artocarpus yang tumbuh di alam liar di wilayah Indonesia [4]. Namun, saat ini sebagian besar sudah sulit ditemukan karena kerusakan lingkungan dan penggunaan lahan untuk perumahan dan industrialisasi. Beberapa tumbuhan dari genus Artocarpus dimanfaatkan sebagai makanan ataupun obat tradisional di India dan negara-negara kawasan Asia Tenggara, termasuk Indonesia. Buah yang dihasilkan dari beberapa spesies Artocarpus umumnya dapat dikonsumsi, sebagaimana sering di temukan di Indonesia berupa Artocarpus heterophyllus (nangka), Artocarpus altilis (sukun), Artocarpus camansi (kluwih) dan Artocarpus integer (cempedak) [5].

Salah satu kandungan kimia yang terdapat dalam semua tumbuhan genus Artocarpus adalah flavonoid [6]. Flavonoid merupakan senyawa polifenol yang penting bagi kesehatan manusia karena aktivitas farmakologisnya yang beragam mulai dari penangkap radikal bebas yang berfungsi sebagai antioksidan, hingga potensinya sebagai agen yang melawan berbagai macam penyakit [7]. Peran flavonoid dalam manusia untuk melawan berbagai penyakit menjadi penting karena banyak penyakit yang disebabkan oleh radikal bebas yang memacu stress oksidatif dan merusak komponen seluler atau mengganggu fungsinya [8,9].

Antioksidan merupakan zat yang mampu menunda atau menghambat kerusakan oksidatif pada molekul target yang diakibatkan oleh radikal bebas. Radikal bebas merupakan atom atau molekul yang mengandung satu atau lebih elektron yang tidak berpasangan. Radikal dapat bermuatan atau tidak bermuatan [10]. Satu molekul antioksidan dapat bereaksi dengan radikal bebas tunggal dan mampu menetralkan radikal bebas dengan menyumbangkan satu elektronnya [11,12]. Antioksidan mampu mencegah dan meringankan penyakit yang disebabkan stres oksidatif karena antioksidan berfungsi mencegah pembentukan spesies radikal oksigen seperti radikal hidroksil, ion radikal superoksida, oksida nitrat, oksida oksidantrinat nitrat, dan radikal peroksi [13] yang bersifat reaktif dan mampu merusak komponen seluler tubuh. Dalam perkembangan keilmuan saat ini, agen yang memiliki sifat antioksidan sering dikategorikan sebagai nutraceuticals karena memiliki berbagai manfaat kesehatan untuk pencegahan terhadap penyakit degeneratif dan penyakit kronis. Selain itu antioksidan banyak digunakan dalam industri makanan sebagai penghambat proses peroksidasi lipid

Review artikel ini membahas tentang profil fitokimia dan aktivitas antioksidan dari 5 tumbuhan genus Artocarpus yang paling sering ditemui di Indonesia, yaitu sukun, kluwih, nangka, cempedak dan tarap. Kajian aspek fitokimia meliputi kandungan kimia yang ada pada daun, akar, batang dan buah dari kelima tumbuhan tersebut; sedangkan kajian aspek aktivitas antioksidan meliputi potensi antioksidan dari kelima tumbuhan tersebut pada beberapa model uji antioksidan. Walaupun aktivitas antioksidan dari beberapa tumbuhan genus artocarpus sudah dipublikasikan, namun belum ada review yang membandingkan dan mengkaji secara komprehensif aktivitas antioksidan beberapa tumbuhan genus artocarpus yang banyak ditemui di Indonesia. Artikel ini diharapkan dapat memberikan gambaran terkini dan ulasan yang komprehensif serta mendalam terhadap kandungan kimia dan potensi antioksidan dari lima tumbuhan genus Artocarpus yang sering ditemui di Indonesia. Hasil studi ini dapat dimanfaatkan untuk mengembangkan lebih lanjut 
tumbuhan genus Artocarpus untuk pengobatan atau pencegahan penyakit serta sebagai inspirasi dalam proses penemuan senyawa bioaktif. Pada artikel ini diketahui bahwa tanaman dengan genus yang sama mempunyai kekerabatan yang erat, sehinggaa menyebabkan adanya kesamaan dalam hal morfologi, kandungan kimia dan potensi farmakologisnya, terutama aktivitas antioksidan.

Metode yang dipakai pada studi ini adalah kajian literatur naratif. Pencarian artikel kajian literatur yang diperoleh dari beberapa database seperti Google Scholar, PubMed, Scopus, dan ScienceDirect. Kombinasi kata kunci yang digunakan dalam pencarian adalah "Artocarpus", "Artocarpus altilis", "Artocarpus heterophyllus", "Artocarpus integer", "Artocarpus camansi", "Artocarpus odoratissimus", "Antioxidant", "Flavonoid", "Phenolics" dan kombinasinya dengan boolean operator untuk mendapatkan data yang diperlukan. Selain itu, pencarian artikel juga berasal dari sumber lain yang terpecaya, misalnya dari buku, naskah tugas akhir mahasiswa, dan naskah paten. Literatur yang digunakan dalam pencarian menggunakan kata kunci adalah artikel jurnal dari rentang 10 tahun terakhir yaitu 2011 hingga 2021. Selain dari artikel utama, beberapa artikel jurnal dan buku diluar rentang tersebut juga digunakan sebagai pendukung data atau informasi tambahan jika diperlukan serta memiliki relevansi. Data yang bersumber dari artikel penelitian terkait aspek morfologi, kandungan kimia bioaktif, dan aktivitas antioksidan dari tumbuhan sukun, kluwih, nangka, cempedak, dan tarap terbatas jumlahnya. Oleh karena itu, semua artikel hasil pencarian digunakan sebagai referensi untuk mendapatkan data yang diperlukan guna penyusunan review artikel ini.

\section{GENUS ARTOCARPUS}

Tumbuhan genus Artocarpus yang terdiri dari 50 spesies dan tersebar dari Asia Selatan, Asia Tenggara, Kepulauan Solomon, India, Kepulauan Pasifik, Australia Utara hingga Amerika Tengah. Di Indonesia Artocarpus dikenal dengan ciri pohonnya tinggi dengan getah putih di seluruh bagian tanaman, kayu keras, buah berdaging dengan banyak biji. Lembar daun tumbuhan genus Artocarpus bertekstur agak keras dengan bulu-bulu halus terutama pada sisi bawah, dengan ukuran daunnya bervariasi [14]. Beberapa tumbuhan genus Artocarpus di Indonesia memproduksi buah-buahan dengan ukuran yang cukup besar dan dapat dimakan manusia, seperti: Artocarpus heterophyllus (nangka), Artocarpus altilis atau nama lainnya, Artocarpus communis (sukun), Artocarpus camansi (kluwih), Artocarpus integer (cempedak), dan Artocarpus odoratissimus (tarap). Sukun dan kluwih merupakan dua tanaman yang sangat mirip daun, batang, bunga, dan pohonnya sehingga masyarakat sulit untuk membedakannya. Namun, keduanya memiliki perbedaan yang sangat mencolok dari buahnya. Sukun tidak memiliki biji dalam buahnya, sedangkan kluwih berbiji. Perkembangbiakan kluwih berasal dari biji (generatif) dan pohonnya memiliki akar tunggang yang kuat; sedangkan sukun diperbanyak secara vegetatif karena tidak memiliki biji. Secara genetika, sukun memiliki kromosom $2 \mathrm{n}=27,28$ dan 56, sedangkan kluwih memiliki kromosom $2 \mathrm{n}=28$ dan 56, yang memperlihatkan kedekatan kekerabatannya. Spesies yang berbeda dalam satu genus mempunyai jumlah kromosom berbeda. Perbedaan kromosom secara umum menggambarkan perbedaan kandungan genetik dan protein suatu spesies yang akan mempengaruhi anatomi, morfologi dan fisiologi antar spesies [15]. Sukun dan kluwih memiliki kemiripan bentuk daun, namun struktur daun dari keduanya sangat berbeda dengan tumbuhan lain dalam genus Artocarpus yang sering ditemui di Indonesia, seperti nangka, cempedak dan tarap. Foto daun, buah, dan bunga kelima spesies tersebut disajikan pada Gambar 1. 


\section{Daun}

Sukun

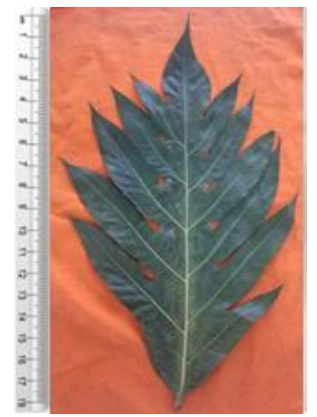

Kluwih

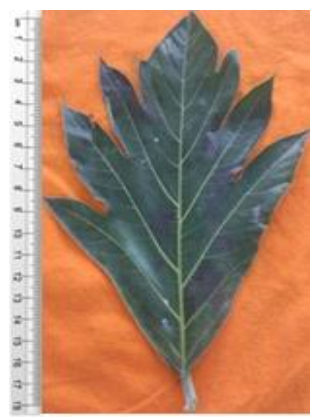

Nangka

Cempedak

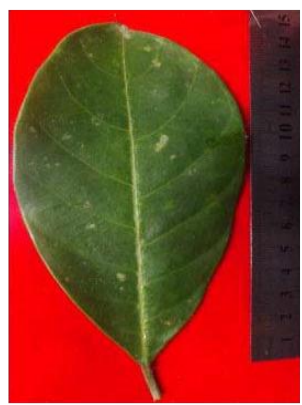

Tarap

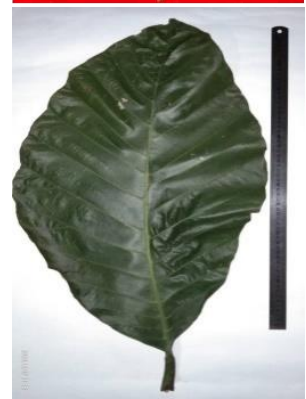

Buah
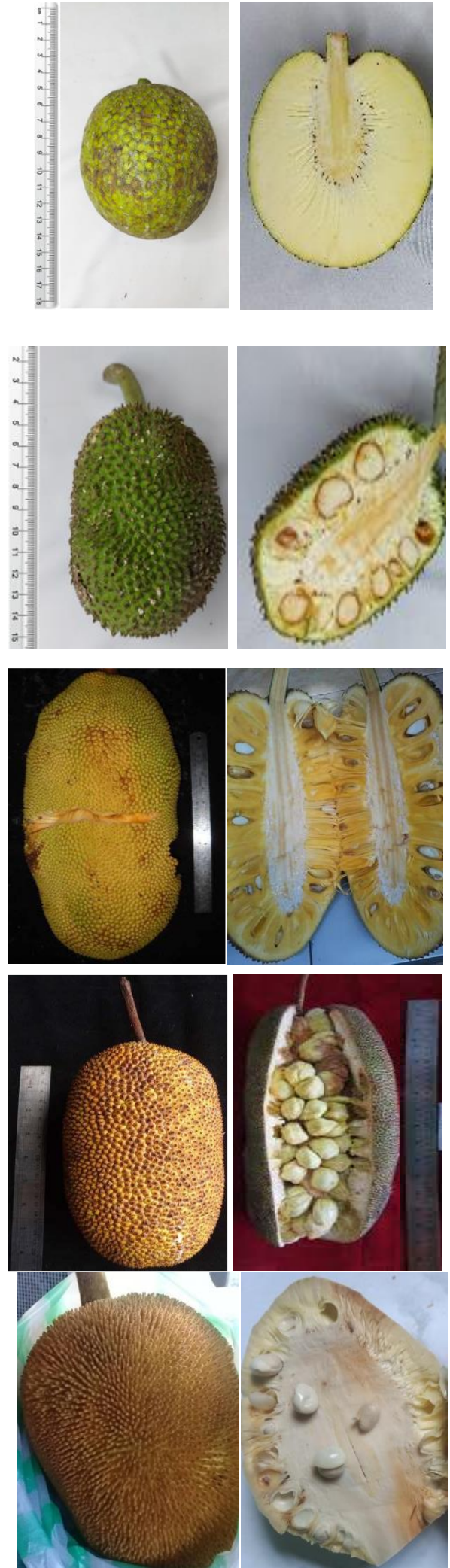

Bunga
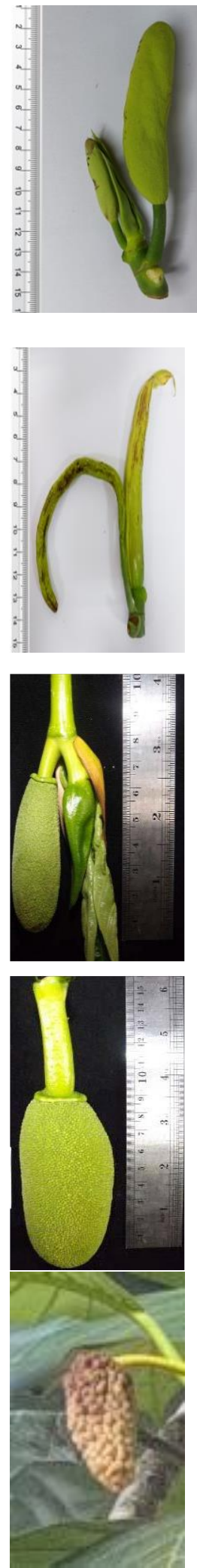

Gambar 1. Perbandingan foto daun, buah dan bunga dari sukun, kluwih, nangka, cempedak dan tarap.

Pada gambar 1 dapat dilihat adanya kemiripan antara daun sukun dan kluwih. Sedangkan daun nangka, cempedak dan tarap secara umum lebih mudah dibedakan karena perbedaan 
morfologinya lebih mudah teramati. Secara lebih detail, perbedaan morfologi beberapa bagian tumbuhan dari kelima spesies tersebut dapat dideskripsikan sebagai berikut:

\subsection{Sukun dan Kluwih}

Kluwih memiliki daun yang berlekuk lebih dangkal, sedangkan daun sukun berlekuk lebih dalam. Bunga jantan tanaman kluwih rata-rata lebih panjang dan bunga betina tanaman kluwih berwarna relatif lebih hijau dibandingkan dengan sukun. Buah kluwih berukuran lebih kecil dibanding dengan buah sukun varietas besar, dan relatif sama besarnya dengan sukun varietas kecil. Permukaan buah kluwih memiliki struktur duri lunak, sedangkan sukun tidak berduri (sukun Bangkok) atau duri lunak sangat pendek (sukun Jawa). Kulit buah kluwih yang masak berwarna hijau dan kulit buah sukun berwarna hijau kekuningan. Buah kluwih tua berisi empulur dengan daging buah sebanyak $\pm 20 \%$, selebihnya berupa biji. Sementara, buah sukun berisi empulur dengan daging buah tanpa biji [15].

\subsection{Nangka}

Nangka memiliki daun yang relatif tebal seperti kulit, letak berseling, panjang tangkai 1-4 $\mathrm{cm}$. Helaian daun nangka berbentuk memanjang atau bulat telur sungsang, tepi rata kadang berlekuk 3-5, ujung meruncing, pangkal menyempit, permukaan atas mengkilap, panjang 7-15 cm, lebar 4,5$10 \mathrm{~cm}$, dan berwarna hijau tua. Bunga nangka ada dalam bulir, berkelamin tunggal dalam satu pohon. Buah tersebut memiliki ukuran yang relatif besar bergantung pada batang atau cabang utama, berbentuk memanjang atau seperti ginjal, panjang $30-90 \mathrm{~cm}$, lebar sekitar $50 \mathrm{~cm}$, berkulit tebal dengan duri pendek berbentuk piramida, berwarna hijau kekuningan, dan berbau keras. Berat buah nangka mencapai $20 \mathrm{~kg}$, dengan daging buah tebal berwarna kuning disekeliling biji. Bijinya berbentuk lonjong dengan ukuran 2,5-4 cm [16].

\subsection{Cempedak}

Cempedak memiliki daun yang hampir sama dengan nangka. Daun cempedak bergantiganti dan tangkai daunnya sepanjang 1-3 cm. Lamina daun berbentuk bulat panjang, ukuran 5-25 $\mathrm{x}$ 2,5-12 cm, alasnya berbentuk bundar hingga bulat, warna hijau mengkilap di bagian atas dan hijau pucat serta pudar di bagian bawah [17]. Bunganya merupakan bunga majemuk yang tersusun dalam bunga periuk berbentuk bulat panjang. Dalam satu pohon terdapat bunga jantan dan bunga betina yang terpisah. Setelah terjadi penyerbukan, bunga betina akan tumbuh menjadi buah. Bentuk buah cempedak adalah bulat memanjang, dengan ukuran panjang sekitar $40 \mathrm{~cm}$ dan garis tengah 15-20 $\mathrm{cm}$. Duri pada permukaan buah tidak setajam dan sekasar buah nangka. Kulit buah cempedak berwarna hijau kekuningan dan setelah tua menjadi kuning agak coklat [18].

\subsection{Tarap}

Daun tarap memiliki warna hijau gelap, berukuran 16-50 x 11-28 cm, bentuknya bundar di batang dan lebih sempit di ujung. Bunga jantan dan betina dari tarap tumbuh secara terpisah di pohon yang sama. Buahnya memiliki ukuran relatif besar dengan panjang $16 \mathrm{~cm}$, diameter $13 \mathrm{~cm}$, dan berat 2,5 kg. Buahnya berbentuk bulat bujur, teratur, dan bertabur tebal dengan duri pendek berwarna kuning kehijauan dan memiliki bulu di kulitnya serta daging buahnya putih kekuningan melekat pada inti pusat yang berair dan beraroma [19]. 


\section{PROFIL FITOKIMIA}

Artocarpus memiliki kandungan kimia senyawa metabolit yang beragam. Tumbuhan genus Artocarpus mempunyai kandungan fitokimia senyawa fenolik termasuk flavonoid, stilbenoid, arilbenzofuron, dan neolignan. Struktur senyawa golongan flavonoid yang sudah pernah dilaporkan memiliki kerangka kalkon, flavanon, flavan-3-ol, flavon, prenilflavon, oxepino flavon, piranoflavon, dihidrobenzoxanton, furanodihidrobenzoxanton, piranodihidrobenzoxanton, quinonoxanton, siklopentenoxanton, xantonolid, dan dihidroxanton. Profil fitokimia dari tumbuhan genus Artocarpus secara lebih detail dijelaskan sebagai berikut:

\subsection{Sukun}

Sebagian besar senyawa bioaktif pada tanaman sukun berasal dari jalur fenilpropanoid, yaitu fenolat dan flavonoid dengan kandungan kimia yang paling banyak dilaporkan sebelumnya adalah senyawa triterpen dan flavonoid [20-24]. Namun secara umum pada daun, kulit dan buah sukun mengandung flavonoid, steroid/triterpenoid, glikosida antrakuinon, tanin, karbohidrat dan saponin. Daun sukun yang diekstraksi dengan metanol dan dipartisi dengan kloroform dapat ditemukan adanya senyawa auron H, auron I dan auron J serta 2 senyawa flavonoid yaitu 8-geranil-4',5,7trihidroksiflavon dan sikloaltilisin 7 [25]. Fraksi etil asetat mengandung senyawa geranil dihidrokalkon, yaitu 1-(2,4-dihidroksifenil)-3-\{4-hidroksi-6,6',9,trimetil-6a,7,8,10a-tetrahidro -6Hdibenzo[b,d]piran-5-yl\}-1-propanon; 1-(2,4-dihidroksifenil)-3-[3,4-dihidro-3,8-dihidroksi-2-me til-2(4-metil-3-pentenil)-2H-1-benzopiran-5-yl]-1-propanon; 1-(2,4-dihidroksifenil)-3-[8-hidroksi-2metil-2-(3,4-epoksi-4-metil-1-pentenil)-2H-1-benzopiran-5-yl]-1-propanon; 1-(2,4-dihidroksifenil)-3[8-hidroksi-2-metil-2-(4-hidroksi-4-metil-2-pentenil)-2H-1-benzo piran-5-yl]-1-propanon; dan 2-[6-hi droksi-3,7-dimetilokta-2(E),7-dienil]-2',3,4,4'-tetrahidroksi dihidrokalkon; dan juga mengandung senyawa geranil flavonoid yaitu 1-(2,4-dihidroksifenil)-3-[8-hidroksi-2-metil-2-(4-metil-3-pentenil)2H-1-benzopiran-5-yl]-1-propanon; 2'-geranil-3',4',7-trihidroksiflavon dan sikloaltilisin 6 [20]. Jalur biosintesis flavonoid dan terpenoid yang bertemu dalam sukun mengakibatkan adanya kandungan senyawa turunan flavonoid terprenilasi atau tergeranilasi seperti 2-geranil-2',3,4,4'-tetrahidroksi dihidrokalkon yang dilaporkan merupakan senyawa utama dalam daun sukun [26]. Senyawa lain yang berhasil diisolasi dari buah dan kulit pohon sukun adalah senyawa golongan terpenoid dengan kerangka sikloartan yaitu sikloartenol [21], sikloeukalenol, 2,4-metilensikloartenon, dan sikloartenon [27].

\subsection{Kluwih}

Kluwih merupakan tumbuhan genus Artocarpus yang memiliki hubungan kekerabatan yang sangat dekat dengan sukun. Bagian tumbuhan keduanya memiliki banyak kemiripan kecuali kulit buah dan terdapatnya biji pada kluwih. Hal ini menyebabkan keduanya memiliki kemiripan kandungan kimia. Sebagaimana sukun, kluwih juga memiliki kandungan utama senyawa flavonoid dan terpenoid [20-22,24,28]. Senyawa turunan terpenoid yang terkandung dalam daun kluwih berupa friedelinol, squalen, $\beta$-sitosterol, stigmasterol, pitol, lupeol, zonaron, dan 9,19-siklolanos-24en-3-ol. Bagian batang menghasilkan poliprenol dan sikloartenol asetat. Bagian kulit yang diekstrak dengan $n$-heksan mengandung $\beta$-amyrin asetat dan sikloeugenol $[29,30]$.

\subsection{Nangka}

Nangka diketahui memiliki kandungan utama senyawa metabolit sebagaimana tumbuhan genus Artocarpus lain seperti fenolik termasuk flavonoid, dan juga terpenoid. Namun, uniknya 
nangka juga mengandung senyawa pektin dan karotenoid yang ada dalam buahnya [31]. Senyawa karetonoid yang ada dalam buah nangka diantaranya adalah $\beta$-karoten, $\alpha$-karoten, $\beta$-zeakaroten, $\alpha$ zeakaroten, $\beta$-karoten-5,6 $\alpha$-epoksida, dan crocetin [32]. Penelitian dari [33] menunjukkan bahwa karotenoid utama pada buah nangka adalah all-trans-lutein, all-trans- $\beta$-carotene, all-trans-neo xanthin, 9-cis-neoxanthin, dan 9-cis-violaxanthin.

Senyawa fenolik dan flavonoid yang diketahui terdapat dalam buah nangka diantaranya adalah asam elenaat, urolitin D, 3-(6-hidroksi-7-metoksi-2H-1,3-benzodioksol-5-yl)prop-2-asam enoat, isoembigenin, dan 6-(2H-1,3-benzodioxol-5-karboniloksi)-3,4,5-trihidroksioksan-2-asam karboksilat [34]. Flavonoid terprenilasi terutama pada posisi cincin A dan C3 yang digunakan untuk proses biosintesis lebih lanjut, ditemukan pada kulit atau batang kayu nangka yakni sikloartokarpin A dan pada akar yakni artokarpin [35]. Artokarpin merupakan senyawa antioksidan isoprenil flavon dengan struktur $5,7,2^{\prime}, 4^{\prime}$-tetrahidroksilasi yang memiliki tiga cincin benzen. Cincin B memiliki bagian 2', $4^{\prime}$-resorsinol dan gugus metoksi pada C-7 cincin A, sedangkan pada Pada C-3 dan C-6 dari artocarpin merupakan substituen isoprenil [36]. Terdapat pula flavonoid sederhana yang tidak terprenilasi antara lain artocarpetin dan norartocarpetin yang diisolasi dari akar kayu nangka. Senyawa arilbenzofuran yang ditemukan juga terprenilasi di kedua cincin. Senyawa tersebut antara lain artoheterofilin A yang diisolasi dari ranting nangka [37]. Getah kering nangka yang diekstrak dengan eter mengandung senyawa terpenoid yaitu 9,19-sikloalanos-3-one-24,25-diol [38]. Dari kulit akar nangka, berhasil diisolasi senyawa artonin C dan artonin D [39].

\subsection{Cempedak}

Kandungan kimia dalam cempedak juga didominasi senyawa golongan terpenoid dan flavonoid. Dari kulit kayu berhasil diisolasi senyawa glutinol yang merupakan triterpenoid pentasiklik dengan kerangka glutan [40]. Kandungan senyawa turunan flavonoid dalam cempedak antara lain senyawa flavanon berupa artokarpanon dari akar kayu, artoindonesianin E dan heteroflavanon A dari kulit batang [27,41]. Selain itu, senyawa piranoflavon metoksi siklo kommunal, dan empat flavonoid (artonin F, heteroflavanon A, kudraflavon C, dan siklokommunol) juga berhasil diidentifikasi dari kulit kayu cempedak [42]. Senyawa yang memiliki kekerabatan dengan flavonoid, yaitu turunan stilbene juga terkandung dalam kayu cempedak. Senyawa stilbene tersebut berupa 3,4-trans-4-isopentenyl-3,5,2',4'-tetrahydroxystilbene, 3,5-trans-4-(3-metil-E-but-1enil)-3,5,2',4'-tetrahidroksistilbena, dan 4-metoksi-2,2-dimetil-6-(2(2,4-dihidroksi)fenil-transetenil) kromen atau artokarben [43].

\subsection{Tarap}

Senyawa bioaktif telah berhasil diisolasi dari berbagai bagian dari tanaman tarap. Flavonoid merupakan senyawa yang paling banyak ditemukan pada spesies ini. Pada bagian akar terdapat senyawa pinocembrin dan pinostrobin, sedangkan bagian kulit batang terdapat traxateryl acetat dan artosimmin yang merupakan turunan pyranoflavon [44,45]. Selain itu, biji tarap juga mengandung senyawa flavonoid berupa hesperidin, diosmin, dan kaemferol; sedangkan daging buahnya mengandung naringin dan quercetin [19]. Selain senyawa golongan flavonoid, terdapat pula senyawa golongan lain dalam tanaman tarap, antara lain triterpenoid seperti $\alpha$-amyrin acetate dan ß-amyrin acetate yang diisolasi dari bagian akarnya. Senyawa steroid seperti $\beta$-sitosterol dan stigmasterol yang terdapat pada bagian daun. Senyawa asam lemak seperti hexyldodecanoate pada kulit kayu, asam lemak tak jenuh pada daging buah, biji dan kulit. Trigliserida tak jenuh juga terdapat 
pada daging buah dan biji $[45,46]$. Tarap juga mengandung senyawa karotenoid yang ditemukan di kulit buah, daging dan bijinya seperti pada buah nangka. Kandungan senyawa ini dalam kulit buah tarap lebih tinggi dibandingkan buah dan bijinya. Pigmen lain yang ada dalam tarap adalah antosianin yang terdapat dalam daging buah dan bijinya [19].<smiles>CC(C)=CCCC1(C)C=Cc2c(cc(O)c3c2OC(c2ccc(O)cc2)CC3=O)O1</smiles>

Cycloaltilisin 7<smiles>COc1cc2oc(-c3ccc(O)cc3O)c(CC=C(C)C)c(=O)c2c(O)c1CC=C(C)C</smiles>

Artocarpin<smiles>COc1cc(OC)c([C@H]2CC(=O)c3c(O)cc(O)cc3O2)c(OC)c1</smiles>

Artoindonesianin E<smiles>CC1=CC(c2c(C(=O)c3ccc(O)c(CCC(C)C)c3C)ccc(C(=O)/C=C/c3ccc(O)cc3O)c2O)C(c2ccc(O)cc2O)CC1</smiles>

Artonin C

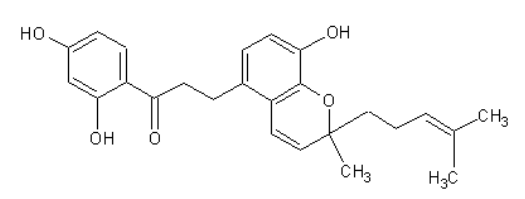

1-(2,4-Dihidroksifenil)-3-[8hidroksi-2-metil-2-(4-metil-3pentenil)-2H-1-benzopiran-5-yl]1-propanon<smiles>COc1cc(O)c2c(=O)cc(-c3ccc(O)cc3O)oc2c1</smiles>
Artocarpetin<smiles>CC(C)=CCc1c(O)cc2oc(-c3ccc(O)cc3O)c(CC=C(C)C)c(=O)c2c1O</smiles>

Cudraflavone C<smiles>CC(C)=CCc1c(O)cc(O)c2c(=O)c(CCC(C)C)c(-c3cc(O)c(O)cc3O)oc12</smiles>

5,7-Dihidroksi-3,8-bis(3-metil-2butenil)-2-(2,4,5-trihidroksifenil)$4 \mathrm{H}-1$-benzopiran-4-one<smiles>CC(C)=CCC/C(C)=C/Cc1c(/C=C/C(=O)c2ccc(O)cc2O)ccc(O)c1O</smiles>

2-geranil-2',3,4,4'tetrahidroksi-dihidrokalkon<smiles>COc1ccc2c(c1)OC(C=C(C)C)C1=C2C2=Cc3cc(O)c(/C=C/C(C)C)c(O)c3C(=O)C2=C1</smiles>

Sikloartocarpin A<smiles>CC(C)=CC1Oc2cc(O)ccc2-c2oc3cc(O)cc(O)c3c(=O)c21</smiles>

Cyclocommunol<smiles>CC(C)=CCc1cc(O)c(O)c2c1Oc1cc(O)cc(O)c1C(=O)c1cc(O)cc(O)c1-2</smiles>

Artosimmin

Gambar 2. Beberapa struktur senyawa turunan flavonoid yang ada di dalam tanaman genus Artocarpus.

\section{AKTIVITAS ANTIOKSIDAN}

Antioksidan alami yang ada dalam buah dan sayuran dapat mengurangi risiko penyakit kronis dan meningkatkan kesehatan manusia [47]. Berdasarkan profil fitokimia dari tumbuhan genus Artocarpus yang telah dipaparkan di atas dan juga penelitian-penelitian sebelumnya [48-50], tumbuhan genus Atocarpus sangat berpotensi untuk dikembangkan sebagai sumber senyawa bioaktif, termasuk sebagai antioksidan. Hal ini menunjukkan bahwa tumbuhan genus Artocarpus yang salah satu kandungan utamanya adalah senyawa fenolik dan flavonoid sangat berpotensi untuk dikembangkan sebagai antioksidan alami. Senyawa fenolik merupakan antioksidan utama 
dalam tumbuhan yang memberikan kemampuan antioksidan dan perlindungan terhadap serangan spesies oksigen reaktif yang berbahaya. Kandungan fenolik total dalam tanaman dapat mempengaruhi kapasitas antioksidannya. Hubungan antara kandungan fenolik total dalam beberapa tumbuhan dengan aktivitas antioksidannya dengan menggunakan berbagai metode sudah diuraikan dalam penelitian-penelitian sebelumnya [51-54].

\subsection{Sukun}

Penelitian sebelumnya oleh [55], menunjukkan bahwa ekstrak air, etanol dan etil asetat dari daun sukun mempunyai aktivitas penangkap radikal DPPH dengan aktivitas terkuat pada ekstrak etil asetat dengan nilai IC 50 sebesar $66,52 \pm 0,70 \mu \mathrm{g} / \mathrm{mL}$ dibandingkan dengan ekstrak etanol $(88,08 \pm$ $5,54 \mu \mathrm{g} / \mathrm{mL})$ dan air $(399,85 \pm 9,48 \mu \mathrm{g} / \mathrm{mL})$. Penelitian yang juga sejalan dengan temuan tersebut menunjukkan bahwa ekstrak metanol daun sukun yang masih segar mempunyai kandungan total fenolik sebesar 144,16 $\pm 17,98 \mathrm{mg} / \mathrm{g}$ dengan persentase aktivitas antioksidan menggunakan metode DPPH sebesar 63,88 $\pm 1,87 \%$. Hasil tersebut menunjukkan aktivitas antioksidan yang kuat [56]. Hasil ini diperkuat dengan penelitian lain bahwa daun sukun segar yang diekstraksi dengan pelarut metanol, etil asetat, dan heksan mempunyai aktivitas penghambatan radikal bebas sebesar 91; 87; dan 22\% (DPPH); 65; 48; dan 39\% (FRAP); 31; 20; dan 9\% (ATBS) pada konsentrasi $100 \mu \mathrm{g} / \mathrm{mL}$ [57]. Ekstrak etanol daun, kulit dan batang sukun memiliki kemampuan untuk menangkap radikal DPPH dan ABTS dengan kategori kuat ( $\mathrm{IC}_{50}<500 \mu \mathrm{g} / \mathrm{mL}$ ). Kemampuan menangkap radikal ABTS lebih kuat dibandingkan dengan DPPH, hal ini menunjukkan bahwa ekstrak etanol daun, kulit dan batang sukun lebih kuat dalam menangkap radikal kationik daripada radikal netral [58]. Hasil uji in vitro terhadap ekstrak etanol daun, batang dan buah sukun memiliki kemampuan menangkap radikal DPPH dengan nilai IC 50 masing-masing sebesar 72, 145, $66 \mu \mathrm{g} / \mathrm{mL}$. Berdasarkan nilai IC 50 dapat dikatakan bahwa ekstrak etanol buah sukun lebih efektif dari ekstrak etanol daun dan batang sukun [59]. Senyawa di dalam daun sukun yang berperan sebagai antioksidan adalah senyawa fenolik dan flavonoid. Senyawa utama yang dimiliki sukun adalah Artocarpin, Artonin E, dan Phytol. Senyawa ini diketahui memiliki bioaktivitas seperti antioksidan [57].

\subsection{Kluwih}

Sebagai tumbuhan yang memiliki kekerabatan paling dekat dengan sukun, maka aktivitas antioksidan dari kluwih hampir mirip dengan sukun. Hal ini didukung dari data fitokimia yang menunjukkan keduanya memiliki kandungan utama senyawa flavonoid dan fenolik yang merupakan senyawa yang berpotensi sebagai antioksidan. Daun kluwih yang diekstraksi dengan pelarut etanol, etil asetat dan $n$-heksan memiliki kemampuan menangkap radikal DPPH dengan nilai IC50 masing-masing ekstrak sebesar 73,16; 73,88 dan 374,7 $\mu \mathrm{g} / \mathrm{mL}$. Kemampuan terbaik ditunjukkan oleh ekstrak etanol daun kluwih. Hasil tersebut berbanding lurus dengan kandungan senyawa fenolik dan flavonoid di dalam daun kluwih. Ekstrak etanol daun kluwih memiliki lebih banyak kandungan 2 senyawa tersebut yaitu sebesar 47,46 \pm 2,2 mgGAE/g dan 79,094 \pm 1,654 mgCE/g dibandingkan dengan ekstrak etil asetat dan ekstrak $n$-heksan daun kluwih [60]. Kemampuan menangkap radikal DPPH juga ditunjukkan pada daun kluwih dengan berbagai kondisi, seperti penelitian dari [61] yang meneliti tentang ekstrak air daun kluwih muda, dewasa, dan tua. Kemampuan penangkapan radikal DPPH dapat dilihat dari nilai IC 50 yang dihasilkan oleh ekstrak air daun kluwih muda, dewasa dan tua masing-masing sebesar 748,02; 1266,17 dan 1377,00 $\mu \mathrm{g} / \mathrm{mL}$. Ekstrak air daun kluwih muda memiliki kemampuan paling besar dibandingkan dengan daun dewasa dan tua. 
Bagian lain dari kluwih yang juga memiliki aktivitas penangkapan radikal DPPH adalah buah. Buah kluwih dipisahkan menjadi 3 bagian yaitu biji, daging dan bagian tengah dari buah. Ketiga bagian tersebut kemudian diekstraksi dengan pelarut metanol $80 \%$ dan air. Hasil pengujian menunjukkan bahwa ekstrak metanol dari ketiga bagian tersebut memiliki kemampuan menangkap radikal lebih baik dibandingkan dengan ekstrak airnya. Hasil \% inhibisi dari ekstrak metanol biji, daging, dan bagian tengah buah kluwih masing-masing sebesar 90,4 $\pm 0,57 ; 87,4 \pm 0,46$; dan 84,9 \pm $1,62 \%$, sedangkan ekstrak air masing-masing sebesar 45,2 $\pm 1,23 ; 39,5 \pm 3,46$ dan 59,9 $\pm 0,81 \%$ [62]. Ekstrak air dari daun dan beberapa bagian buah (kulit, daging dan biji) kluwih mempunyai aktivitas antioksidan terhadap radikal DPPH dengan nilai IC 50 berkisar antara 80 sampai $250 \mu \mathrm{g} / \mathrm{mL}$. Ekstrak air dari biji dan daun kluwih menunjukkan aktivitas yang kuat (50-100 $\mu \mathrm{g} / \mathrm{mL})$, kulit buah kluwih memiliki aktivitas yang sedang (101-150 $\mu \mathrm{g} / \mathrm{mL})$, dan daging buah kluwih memiliki aktivitas yang rendah $(>150 \mu \mathrm{g} / \mathrm{mL})$ [63]. Senyawa yang berperan sebagai antioksidan antara lain $\beta$-sitosterol pada daun, sikloartenol asetat pada batang, $\beta$-amyrin asetat dan sikloeugenol pada kulit $[29,30]$.

\subsection{Nangka}

Kandungan senyawa bioaktif yang terdapat di dalam tanaman nangka juga dapat dimanfaatkan sebagai antioksidan. Beberapa penelitian terkait bagian dari tanaman ini sudah pernah dilakukan. Penelitian menunjukkan bahwa ekstrak etanol biji nangka memiliki aktivitas antioksidan terhadap radikal DPPH sebesar 50,09\% (IC50: $300 \mu \mathrm{g} / \mathrm{mL}$ ), sedangkan terhadap radikal ABTS sebesar 51,89\% (IC50: $290 \mu \mathrm{g} / \mathrm{mL}$ ) [6]. Biji nangka yang diekstraksi dengan diklorometan-metanol (1:1) menunjukkan aktivitas penangkapan radikal lebih tinggi (IC50: 643,33 $\pm 2,90 \mu \mathrm{g} / \mathrm{mL}$ ) dibandingkan dengan ekstrak aseton (IC50: 786,70 \pm 10,40 $\mu \mathrm{g} / \mathrm{mL}$ ) pada uji dengan radikal DPPH; sedangkan pada uji dengan ABTS ekstrak aseton ( $\mathrm{IC}_{50}: 49,10 \pm 0,50 \mu \mathrm{g} / \mathrm{mL}$ ) memiliki aktivitas yang lebih kuat dibandingkan dengan ekstrak diklorometan-metanol (1:1) (IC 50: 55,60 $\pm 0,20 \mu \mathrm{g} / \mathrm{mL}$ ) [64]. Pada bagian daun nangka yang diuji dengan metode DPPH, FRAP, dan ABTS menunjukkan adanya aktivitas antioksidan yang kuat. Daun nangka yang diekstraksi dengan air memiliki kemampuan menangkap radikal DPPH terkuat dibandingkan dengan fraksi air dan fraksi etil asetat daun nangka dengan nilai IC 50 masing-masing sebesar 73,5 $\pm 1,8 ; 219,9 \pm 3,5$; dan 235,8 $\pm 2,9 \mu \mathrm{g} / \mathrm{mL}$. Dalam uji FRAP, nilai IC 50 dari ekstrak air, fraksi air dan fraksi etil asetat daun nangka masing-masing sebesar 565,8 $\pm 2,5 ; 72,0$ $\pm 2,9$; dan 342,0 $\pm 2,6 \mu \mathrm{M} \mathrm{Fe}$ (II)/g. Sedangkan uji ABTS pada ekstrak air, fraksi air dan fraksi etil asetat daun nangka menghasilkan TEAC value masing-masing sebesar 34,8 $\pm 1,03 ; 28,6 \pm 1,5$ dan 5,9 $\pm 0,09$ $\mu \mathrm{M}$ TE/g [65]. Penelitian lain oleh [66], terhadap daun nangka yang diekstraksi dengan etanol menunjukkan aktivitas antioksidan terhadap radikal DPPH dengan IC 50 sebesar 152,1 \pm 30,20 $\mu \mathrm{g} / \mathrm{mL}$, sedangkan terhadap radikal ABTS sebesar 17,26 $\pm 1,66 \mu \mathrm{g} / \mathrm{mL}$.

Dari hasil tersebut, aktivitas terhadap radikal ABTS lebih kuat dibandingkan terhadap radikal DPPH. Hal ini dikarenakan radikal ABTS bereaksi dengan senyawa hidrofilik dan lipofilik secara bersamaan sedangkan radikal DPPH hanya bereaksi dengan senyawa hidrofilik. Bagian buah nangka yang diekstraksi dengan etanol memiliki kemampuan yang lemah untuk menangkap radikal DPPH dengan nilai IC 50 sebesar $410 \mu \mathrm{g} / \mathrm{mL}$ [67]. Senyawa yang berperan terhadap aktivitas antioksidan di dalam biji nangka adalah senyawa fenolik dan flavonoid [6]. Senyawa lain yang dilaporkan antara lain cycloartenone, cycloartenol, $\beta$-sitosterol dan tannin yang dapat ditemukan pada daun nangka [65]. 


\subsection{Cempedak}

Cempedak memiliki aktivitas antioksidan berdasarkan hasil dari beberapa penelitian sebelumnya yang menunjukkan bahwa bagian yang paling eksotis dari cempedak adalah buahnya karena memiliki aroma khas yang paling kuat dibandingkan tumbuhan lain dalam genus Artocarpus. Ekstrak metanol dari buah cempedak (meliputi kulit, biji dan daging buah) memiliki potensi sebagai antioksidan. Hasil uji aktivitas antioksidan dengan penangkapan radikal DPPH, ATBS dan metode FRAP menunjukkan bahwa bagian kulit buah cempedak memiliki aktivitas antioksidan yang yang paling kuat, sedangkan daging buahnya memiliki aktivitas antioksidan yang paling rendah [68]. Penelitian lain oleh [69] menggunakan buah cempedak yang dibuat dalam bentuk puree dengan menambahkan maltodekstrin yang kemudian dibuat serbuk dengan freeze-drying. Pengujian pada serbuk tersebut yang dilarutkan dalam air suling menunjukkan aktivitas antioksidan terhadap radikal DPPH sebesar 52,12\% pada konsentrasi $50 \mu \mathrm{g} / \mathrm{mL}$. Pada penelitian tersebut senyawa yang berperan sebagai antioksidan adalah $\beta$-karoten yang terkandung didalamnya sebesar $15,83 \mathrm{mg} / \mathrm{g}$. Aktivitas yang sama ditunjukkan juga dari kulit buah cempedak yang dikeringkan pada suhu $45^{\circ} \mathrm{C}$ dan diekstraksi dengan pelarut etanol 95\%. Ekstrak ini memiliki kemampuan untuk menangkap radikal DPPH dengan nilai IC50 sebesar 56,96 $\mu \mathrm{g} / \mathrm{mL}$ [50].

\subsection{Tarap}

Dari kelima tumbuhan yang dibahas dalam artikel ini, tarap merupakan yang paling sulit ditemui karena hanya tumbuh di beberapa daerah di Indonesia yang salah satunya di wilayah Borneo (Kalimantan). Penelitian tentang tumbuhan ini juga masih sangat minimal sehingga potensinya untuk diteliti masih besar. Aktivitas antioksidan dari ekstrak etanol, etil asetat, dan kloroform kulit batang tarap menunjukkan aktivitas penghambatan yang lemah terhadap radikal DPPH dengan nilai $\mathrm{IC}_{50}>120 \mu \mathrm{g} / \mathrm{mL}$ dan persen penghambatan masing-masing sebesar 24,1; 45,1; dan 1,7\% [70]. Bagian lain yang diteliti aktivitas antioksidannya dengan metode DPPH dan FRAP adalah buah tarap yang diambil daging dan bijinya kemudian diekstraksi dengan metanol $80 \%$. Hasilnya kedua bagian dari buah tersebut memiliki aktivitas sebagai antioksidan. Konsentrasi yang dihasilkan daging buah sebesar 2,44 mg AEAC/g pada metode DPPH dan 116,7 $\mu \mathrm{M} \mathrm{Fe(II)/g} \mathrm{pada}$ metode FRAP, sedangkan pada biji buah sebesar 13,69 mg AEAC/g pada metode DPPH dan 208,67 $\mu \mathrm{M}$ Fe(II)/g pada metode FRAP [71].

Senyawa yang berperan sebagai antioksidan pada kulit batang tarap adalah artosimmin yang terdiri dari cincin 3',4'-dioksigenasi. Senyawa ini menghasilkan daya penghambatan radikal DPPH sebesar 79,5\% dengan nilai $\mathrm{IC}_{50} 32,1 \mu \mathrm{g} / \mathrm{mL}$ [70]. Senyawa lain yang juga memiliki aktivitas antioksidan antara lain fenol, glikosida fenolik, flavonoid, antosianin dan asam amino aromatik yang terdapat dalam buah (71), sedangkan pada akar terdapat senyawa pinocembrin [49]. 
Tabel 1. Aktivitas antioksidan beberapa senyawa yang berasal dari beberapa tumbuhan genus Artocarpus.

\begin{tabular}{|c|c|c|c|c|}
\hline Tanaman & Bagian & Nama Senyawa & Aktivitas Antioksidan & Referensi \\
\hline Sukun & Daun & $\begin{array}{l}\text { artocarpin, artonin E } \\
\text { dan phytol }\end{array}$ & $\begin{array}{l}\text { Memiliki aktivitas antioksidan terhadap } \\
\text { radikal DPPH, FRAP dan ABTS, dengan } \\
\text { aktivitas masing-masing sebesar 22-91\% } \\
\text { (DPPH); 39-65\% (FRAP); 9-31\% (ATBS) } \\
\text { pada konsentrasi } 100 \mu \mathrm{g} / \mathrm{mL}\end{array}$ & [57] \\
\hline Kluwih & Buah & $\begin{array}{c}\beta \text {-amyrin asetat dan } \\
\text { sikloeugenol }\end{array}$ & $\begin{array}{l}\text { Memiliki aktivitas antioksidan terhadap } \\
\text { radikal DPPH dengan } \mathrm{IC}_{50} \text { berkisar } \\
\text { antara } 80 \text { sampai } 250 \mu \mathrm{g} / \mathrm{mL} \text {. Bagian biji } \\
\text { memiliki aktivitas kuat ( } 50-100 \mu \mathrm{g} / \mathrm{mL}) \text {, } \\
\text { Bagian kulit memiliki aktivitas yang } \\
\text { sedang (101-150 } \mu \mathrm{g} / \mathrm{mL}) \text {, dan daging } \\
\text { memiliki aktivitas rendah (>150 } \mu \mathrm{g} / \mathrm{mL})\end{array}$ & {$[30,63]$} \\
\hline Nangka & Daun & $\begin{array}{c}\text { cycloartenone, } \\
\text { cycloartenol, } \beta \text { - } \\
\text { sitosterol dan tannin }\end{array}$ & $\begin{array}{l}\text { Memiliki aktivitas antioksidan terhadap } \\
\text { radikal DPPH dengan } \mathrm{IC}_{50} \text { sebesar } 152,1 \\
\pm 30,20 \mu \mathrm{g} / \mathrm{mL} \text {, sedangkan terhadap } \\
\text { radikal ABTS sebesar } 17,26 \pm 1,66 \mu \mathrm{g} / \mathrm{mL}\end{array}$ & {$[65,72]$} \\
\hline Cempedak & Buah & $\beta$-karoten & $\begin{array}{l}\text { Memiliki aktivitas antioksidan } \\
\text { terhadap radikal DPPH sebesar 52,12\% } \\
\text { pada konsentrasi } 50 \mu \mathrm{g} / \mathrm{mL}\end{array}$ & [69] \\
\hline Tarap & Batang & artosimmin & $\begin{array}{l}\text { Memiliki aktivitas penghambatan yang } \\
\text { lemah terhadap radikal DPPH dengan } \\
\mathrm{IC}_{50}>120 \mu \mathrm{g} / \mathrm{mL}\end{array}$ & {$[70]$} \\
\hline
\end{tabular}

Tabel 1 dan uraian diatas meyajikan aktivitas antioksidan dari kelima tumbuhan genus Artocarpus. Beberapa metode uji antioksidan yang digunakan menghasilkan senyawa aktif yang berbeda dengan besar potensi antioksidan yang sangat beragam. Singkatnya, selain kandungan tannin yang tersebar dalam daun genus Artocarpus, beberapa senyawa antioksidan yang menonjol dalam tumbuhan genus Artocarpus cycloartenone dan cycloartenol dalam daun nangka; artocarpin dan artonin E dalam daun sukun dan keluwih; pinocembrin dan pinostrobin dalam akar, artosimmin dalam kulit batang tarap; sedangkan dalam cempedak terkandung artoindonesianin $\mathrm{E}$, heteroflavanon A, artonin F, kudraflavon C, dan siklokommunol pada kulit batangnya. Secara umum, hasil kajian literatur dalam artikel ini menunjukkan adanya kesamaan kandungan utama senyawa fenoliknya dan adanya beberapa senyawa fenolik dengan gugus prenil dan geranil yang memiliki potensi antioksi, serta adanya hubungan antara kandungan fenolik terhadap aktivitas antioksidan yang sejalan dengan temuan sebelumnya [55]. Sukun dan kluwih merupakan tumbuhan genus Artocarpus yang paling memiliki kesamaan morfologi bagian tumbuhan (kecuali kulit buahnya) serta memiliki kemiripan yang tinggi dalam kandungan kimia.

Artikel review ini menyajikan karakteristik morfologi, kandungan kimia dan aktivitas farmakologi dari tumbuhan genus Artocarpus yang ada sering ditemui di Indonesian. Dalam 
membandingkan aktivitas antioksidan antar esktrak tumbuhan ataupun antar senyawa, idealnya dilakukan dengan mengambil data dari artikel yang sama (untuk mengurangi bias dan perbedaan dalam metodologi). Hal ini tidak dapat dilakukan karena keterbatasan sumber pustaka yang tersedia untuk penyusunan review artikel ini. Selain itu, diperlukan artikel yang lebih banyak untuk memperoleh gambaran yang lebih komprehensif dan konsisten. Keterbatasan jumlah penelitian dari beberapa tumbuhan (misalnya tarap dan cempedak) menyebabkan perbandingan antar spesies belum bisa dilakukan secara lebih detail dan komprehensif.

\section{KESIMPULAN}

Artikel ini mengulas aspek morfologi, fitokimia, dan antioksidan dari beberapa tumbuhan genus Artocarpus yang paing sering ditemui di Indonesia. Kelima tumbuhan genus Artocarpus yang diulas dalam penelitian ini memiliki karakteristik morfologi yang berbeda-beda. Pohon sukun dan kluwih (daun, batang, bunga) memilki kimiripan yang sangat tinggi sehingga sulit dibedakan orang awam. Namun, kulit buah dan bijinya dapat dibedakan dengan mudah. Tumbuhan dari genus Artocarpus memiliki kandungan kimia yang beragam, namun senyawa terpenoid dan fenolik, terutama flavonoid merupakan kandungan utama tumbuhan dari genus ini. Salah satu senyawa khas dalam genus ini adalah adanya flavonoid terprenilasi dan tergeranilasi yang merupakan pertemuan jalur biosintesis flavonoid dan terpenoid. Ekstrak dari semua bagian dari tumbuhan-tumbuhan tersebut umumnya memiliki aktivitas antioksidan dengan kekuatan yang beragam tergantung jenis pelarut yang digunakan dan metode uji antioksidannya.

Funding: Penelitian ini dibiayai oleh Deputi Bidang Penguatan Riset dan Pengembangan, Kementrian Riset dan Teknologi/Badan Riset Nasional dan Inovasi Nasional, melalui Hibah PDUPT nomor kontrak 1625/UN1/DITLIT/DIT-LIT/PT/2021.

Acknowledgments: Penulis mengucapkan terima kasih yang sebesar-besarnya kepada Deputi Bidang Penguatan Riset dan Pengembangan, Kementerian Riset dan Teknologi / Badan Riset dan Inovasi Nasional, Republik Indonesia lewat skema hibah PDUPT yang telah mendukung penelitian ini. Artikel ini digunakan oleh AIS untuk melengkapi persyaratan dalam memperoleh gelar Magister.

Conflicts of interest: "Seluruh penulis menyatakan tidak memiliki konflik kepentingan dalam penulisan artikel ini".

\section{Referensi}

1. Awuchi CG. The Biochemistry, Toxicology, and Uses of the Pharmacologically Active Phytochemicals: Alkaloids, Terpenes, Polyphenols, and Glycosides. Journal of Food and Pharmaceutical Sciences. 2019 Nov 27;2019(3):2-2.

2. Ridho MH, Gani AP, Wahyuono S, Fakhrudin N. Application of Ultrasonic-Assisted Fractionation with Full-Factorial Design for the Production of Alkaloid-Rich Fraction from Ficus septica Leaves. Journal of Food and Pharmaceutical Sciences. 2020 Nov 23;8(3):1-1.

3. Hari A, Revikumar KG, Divya D. Artocarpus, a Review of Its Phytochemistry and Pharmacology. Journal of Pharma Search. 2014;9(1):7-12. 
4. Heyne K. Tumbuhan Berguna Indonesia. Jakarta: Yayasan Sarana Wana Jaya; 1987.

5. Verheij EWM, Coronel RE. Plant Resources of South-East Asia. No.2. Bogor Indonesia: Prosea; 1992.

6. Shanmugapriya K, Saravana PS, Payal H, Mohammed SP, Binnie W. Antioxidant Activity, Total Phenolic And Flavonoid Contents Of Artocarpus heterophyllus And Manilkara zapota Seeds And Its Reduction Potential. International Journal of Pharmacy and Pharmaceutical Sciences. 2011;3:256-60.

7. Williams RJ, Spencer JPE, Rice-Evans C. Flavonoids: Antioxidants or signalling molecules? Free Radical Biology and Medicine. 2004;36(7):838-49.

8. Maddu N. Diseases Related to Types of Free Radicals. In: Antioxidants. IntechOpen; 2019. p. 118.

9. Fuloria S, Subramaniyan V, Karupiah S, Kumari U, Sathasivam K, Meenakshi DU, et al. Comprehensive review of methodology to detect reactive oxygen species (Ros) in mammalian species and establish its relationship with antioxidants and cancer. Antioxidants. 2021;10(1):135.

10. Siraki AG, Klotz L-O, Kehrer JP. Free Radicals and Reactive Oxygen Species. Comprehensive Toxicology. Elsevier Inc.; 2018. 262-294 p.

11. Sen S, Chakraborty R, Sridhar C, Reddy YSR, De B. Free radicals, antioxidants, diseases and phytomedicines: Current status and future prospect. International Journal of Pharmaceutical Sciences Review and Research. 2010;3(1):91-100.

12. Bhattacharya S. Reactive Oxygen Species and Cellular Defense System. Free Radicals in Human Health and Disease. 2015;2:1-430.

13. Halliwell B, Gutteridge JMC. Free Radicals in Biology and Medicine. Fifth Edit. Oxford, New York: Oxford University Press; 2015. 944 p.

14. Jansen S, Verheij EWM, Coronel RE. Sumber Daya Nabati Asia Tenggara (PROSEA) : Buahbuahan yang dapat dimakan. In: Plant Resource of South Asia. Jakarta: Penerbit Gramedia; 1997. p. 103-6.

15. Pitojo S. Budidaya Keluwih. Yogyakarta: Kanisius; 2009. 64 p.

16. Dalimartha S. Atlas Tumbuhan Obat Indonesia: Menguak Kekayaan Tumbuhan Obat Indonesia. Niaga Swadaya; 2008. 118-119 p.

17. de Almeida Lopes MM, de Souza KO, de Oliveira Silva E. Cempedak-Artocarpus champeden. In: Rodrigues S, de Oliveira Silva E, de Brito ES, editors. Exotic Fruits. Academic Press; 2018. p. $121-7$.

18. Widyastuti YE. Nangka dan Cempedak: Ragam Jenis dan Pembudidayaan. Penebar Swadaya; 1995. $110 \mathrm{p}$.

19. Abu Bakar FI, Abu Bakar MF, Rodrigues S, de Oliveira Silva E, de Brito ES. Tarap - Artocarpus odoratissimus. In: Exotic Fruits. Academic Press; 2018. p. 413-8.

20. Wang Y, Xu K, Lin L, Pan Y, Zheng X. Geranyl flavonoids from the leaves of Artocarpus altilis. 2007;68:1300-6.

21. Altman LJ, Zito SW. Sterols and Triterpenes from the Fruit of Artocarpus altilis. Phytochemistry. 1976;15:829-30. 
22. Patil AD, Freyer AJ, Killmer L, Offen P, Taylor PB, Votta BJ, et al. A New Dimeric Dihydrochalcone and a New Prenylated Flavone from the Bud Covers of Artocarpus altilis : Potent Inhibitors of Cathepsin K. Journal of Natural Products. 2002;65(4):624-7.

23. Prior RL. Fruit and Vegetables in the Prevention of Cellular Oxidative Damage. American Journal of Clinical Nutrition. 2003;78.

24. Han A, Kang Y, Windono T, Lee SK, Seo E. Prenylated Flavonoids from the Heartwood of Artocarpus communis with Inhibitory Activity on Lipopolysaccharide-Induced Nitric Oxide Production. Journal of Natural Products. 2006;69(4):719-21.

25. Thi N, Mai T, Hai NX, Phu DH, Nguyen P, Trong H, et al. Phytochemistry Letters Three new geranyl aurones from the leaves of Artocarpus altilis. Phytochemistry Letters. 2012;5(3):647-50.

26. Fakhrudin N, Pertiwi KK, Takubessi MI, Susiani EF, Nurrochmad A, Widyarini S, et al. A geranylated chalcone with antiplatelet activity from the leaves of breadfruit (Artocarpus altilis). Pharmacia. 2020;67(4):173-80.

27. Achmad SA, Hakim EH, Juliawaty LD, Makmur L, Syah YM, Aimi N, et al. Prenylated flavonoids and related compounds of the Indonesian Artocarpus (Moraceae). J Nat Med. 2006;60:161-84.

28. Chan S, Ko H, Lin C. New Prenylflavonoids from Artocarpus communis. Journal of Natural Products. 2003;66(3):427-30.

29. Tsai PW, De Castro-Cruz KA, Shen CC, Chiou CT, Ragasa CY. Chemical constituents of Artocarpus camansi. Pharmacognosy Journal. 2013;5(2):80-2.

30. Nasution R, Muhabbah N, Helwati H, Bahi M, Marianne M, Amna U. Isolation of Lupeol Acetate from Fruit Peels of Artocarpus camansi. Journal of Advanced Pharmaceutical Technology \& Research. 2020;11(3):148-56.

31. Vazhacharickal PJ, Sajeshkumar NK, Mathew JJ, Kuriakose AC, Abraham B, Mathew RJ, et al. CHEMISTRY AND MEDICINAL PROPERTIES OF JACKFRUIT (ARTOCARPUS HETEROPHYLLUS): A REVIEW ON CURRENT STATUS OF KNOWLEDGE. International Journal of Innovative Research and Review. 2015;3(2):83-95.

32. Chandrika UG, Jansz ER, Warnasuriya ND. Analysis of Carotenoids in Ripe Jackfruit (Artocarpus heterophyllus) Kernel and Study of Their Bioconversion in Rats. Journal of the Science of Food and Agriculture. 2005 Jan 30;85(2):186-90.

33. De Faria AF, De Rosso V V, Mercadante AZ. Carotenoid Composition of Jackfruit (Artocarpus heterophyllus), Determined by HPLC-PDA-MS/MS. Plant Foods for Human Nutrition. 2009;64(2):108-15.

34. Li Z, Lan Y, Miao J, Chen X, Chen B, Liu G, et al. Phytochemicals, antioxidant capacity and cytoprotective effects of jackfruit (Artocarpus heterophyllus Lam.) axis extracts on HepG2 cells. Food Bioscience. 2021 Jun 1;41:100933.

35. Lin CN, Lu CM, Huang PL. Flavonoids from Artocarpus heterophyllus. Phytochemistry. 1995 Aug 1;39(6):1447-51.

36. Wong SK, Tangah J, Chan HT, Chan EWC. Chemistry and pharmacology of artocarpin: An isoprenyl flavone from artocarpus species. Systematic Reviews in Pharmacy. 2018;9(1):58-63.

37. Zheng ZP, Chen S, Wang S, Wang XC, Cheng KW, Wu JJ, et al. Chemical components and tyrosinase inhibitors from the twigs of Artocarpus heterophyllus. Journal of Agricultural and Food Chemistry. 2009 Aug 12;57(15):6649-55. 
38. Barik BR, Bhaumik T, Dey AK, Kundu AB. Triterpenoids from Artocarpus heterophyllus. Phytochemistry. 1994 Mar 1;35(4):1001-4.

39. Hano Y, Aida M, Nomura T. Two New Natural Diels-Alder-Type Adducts from the Root Bark of Artocarpus heterophyllus. Journal of Natural Products. 1990;53(2):391-5.

40. Achmad SA, Hakim EH, Juliawaty LD, Makmur L, Sutoyo S, Aimi N, et al. A New Prenylated Flavone from Artocarpus champeden. Journal of Natural Products. 1996 Sep 1;59(9):878-9.

41. Djakaria YK. Artocarpanone, A Flavanone Derivative from Root Trunk of Artocarpus champeden Spreng. Institute of Technology, Bandung; 1999.

42. Shah MKK, Sirat HM, Jamil S, Jalil J. Flavonoids from the Bark of Artocarpus integer var. silvestris and their Anti-inflammatory Properties. Natural Product Communications. 2016;11(9):1275-8.

43. Boonlaksiri C, Oonanant W, Kongsaeree P, Kittakoop P, Tanticharoen M, Thebtaranonth Y. An antimalarial stilbene from Artocarpus integer. Phytochemistry. 2000 Jun 1;54(4):415-7.

44. C.L. Ee G, H. Teo S, Rahmani M, K. Lim C, M. Lim Y, F.J. Bong C. Artosimmin- A Potential Anti-Cancer Lead Compound from Artocarpus odoratissimus. Letters in Organic Chemistry. 2010 Apr 14;7(3):240-4.

45. Yen KH, Nyokat N, Kutoi CJ, Hamzah AS, Lim IF. Chemical Constituents of Artocarpus odoratissimus from Sarawak. Journal of Applied Pharmaceutical Science. 2017 Aug 1;7(8):13741.

46. Ragasa CY, Antonio Ng V, Hun Park J, Woo Kim D, Cornelio K, Shen C-C. Chemical Constituents of Artocarpus altilis and Artocarpus odoratissimus. Research Journal of Pharmaceutical, Biological and Chemical Sciences. 2014;5(4):1081-7.

47. Jideani AIO, Silungwe H, Takalani T, Omolola AO, Udeh HO, Anyasi TA. Antioxidant-rich natural fruit and vegetable products and human health. Vol. 24, International Journal of Food Properties. South Africa: Bellwether Publishing, Ltd.; 2021. p. 41-67.

48. Daud MNH, Fatanah DN, Abdullah N, Ahmad R. Evaluation of antioxidant potential of Artocarpus heterophyllus L. J33 variety fruit waste from different extraction methods and identification of phenolic constituents by LCMS. Food Chemistry. 2017 Oct 1;232:621-32.

49. Ali MdY, Morshed MdR, Hossen MdS, Tanvir EM, Kabir A, Islam MdA, et al. Antioxidant Properties and Dose-Dependent Effects of Monkey Fruits ( Artocarpus lakoocha ) against Paracetamol-Induced Hepato-Renal Toxicity in Rats . American Journal of Pharmacology and Toxicology. 2018 Jan 1;13(1):16-29.

50. Rahmadi A, Sabarina Y, Agustin S. Different drying temperatures modulate chemical and antioxidant properties of mandai cempedak (Artocarpus integer). F1000Research. 2020;7.

51. Piluzza G, Bullitta S. Correlations between phenolic content and antioxidant properties in twenty-four plant species of traditional ethnoveterinary use in the Mediterranean area. Pharmaceutical Biology. 2011 Mar;49(3):240-7.

52. Duda SC, arghitas LAM, Dezmireana D, Dudab M, aoana RM arg, Bobis O. Changes in major bioactive compounds with antioxidant activity of Agastache foeniculum, Lavandula angustifolia, Melissa officinalis and Nepeta cataria: Effect of harvest time and plant species. Industrial Crops and Products. 2015;77:499-507.

53. Gan J, Feng Y, He Z, Li X, Zhang H. Correlations between Antioxidant Activity and Alkaloids and Phenols of Maca (Lepidium meyenii). Journal of Food Quality. 2017;2017. 
54. Kainama H, Fatmawati S, Santoso M, Papilaya PM, Ersam T. The Relationship of Free Radical Scavenging and Total Phenolic and Flavonoid Contents of Garcinia lasoar PAM. Pharmaceutical Chemistry Journal. 2020 Mar 1;53(12):1151-7.

55. Fakhrudin N, Khairunnisa SY, Azzahra A, Ajiningtyas RJ. Study of radical scavenger activity, total phenol and flavonoid contents of Artocarpus altilis leaves extracts. International Journal of Pharmaceutical and Clinical Research. 2016;8(5):352-6.

56. Leng LY, Nadzri NB, Yee KC, Abdul Razak NB, Shaari AR. Antioxidant and Total Phenolic Content of Breadfruit (Artocarpus altilis) Leaves. MATEC Web of Conferences. 2018;150.

57. Mainasara MM, Bakar MFA. Phytochemical Constituents, Antioxidant And Antiproliferative Properties Of Artocarpus altilis (Sukun) From Endau Rompin, Johor, Malaysia. Science World Journal. 2019;14(3):124-35.

58. Mat Saad H, Tan CH, Lim SH, Manickam S, Sim KS. Evaluation of anti-melanogenesis and free radical scavenging activities of five Artocarpus species for cosmeceutical applications. Industrial Crops and Products. 2021 Mar 1;161:113184.

59. Palupi DHS, Retnoningrum DS, Iwo MI, Soemardji AA. Leaf Extract Of Artocarpus altilis [Park.] Fosberg has Potency as Antiinflammatory, Antioxidant, and Immunosuppressant. Rasayan Journal of Chemistry. 2020;13(1):636-46.

60. Vianney YM, Amanda N, Pieknell K, Johan CW, Hardjo PH. Evaluation of the Antioxidant and Antibacterial Activity of Breadnut (Artocarpus camansi Blanco) Leaf Extracts. Vol. 9, Indian Journal of Natural Products and Resources. 2018.

61. Permata DA, Asben A. Inhibition Activity of Alpha Amylase and Antioxidant Activity of Breadnut ( Artocarpus camansi ) Leaf Extract from Different Leaf Position. Indian Journal of Agricultural Biochemistry. 2019 Jun 1;32(1):89.

62. Rabeta MS, Syafiqah MJN. Proximate Composition, Mineral and Total Phenolic Contents, and Scavenging Activity of Breadnut Fruit (Artocarpus camansi). J Trop Agric and Fd Sc. 2016;44(1):1-7.

63. Vianney YM, Putra SED, Purwanto MGM. Antioxidant and toxicity activity of aqueous extracts from various parts of breadfruit and breadnut. International Journal of Fruit Science. 2020;20(S3):S1639-51.

64. Devi PSS, Kumar NS, Sabu KK. Phytochemical profiling and antioxidant activities of different parts of Artocarpus heterophyllus Lam. (Moraceae): A review on current status of knowledge. Future Journal of Pharmaceutical Sciences 2021 7:1. 2021 Jan 28;7(1):1-7.

65. Loizzo MR, Tundis R, Chandrika UG, Abeysekera AM, Menichini F, Frega NG. Antioxidant and Antibacterial Activities on Foodborne Pathogens of Artocarpus heterophyllus lam. (Moraceae) Leaves Extracts. Journal of Food Science. 2010 Jun;75(5).

66. Ngbolua K te N, Moke EL, Blaise M-M, Bongo GN, Kapepula PM, Ngombe NK, et al. Selenium Content, Anthelmintic, Antioxidant and Antibacterial Activities of Artocarpus Heterophyllus Lam. From Ubangi Ecoregion in Democratic Republic of the Congo. American Journal of Biomedical Science \& Research. 2019;6(2):135-41.

67. Soubir T. Antioxidant Activities of Some Local Bangladeshi Fruits (Artocarpus heterophyllus, Annona squamosa, Terminalia bellirica, Syzygium samarangense, Averrhoa carambola and Olea europa). Sheng $\mathrm{Wu}$ Gong Cheng Xue Bao = Chinese Journal of Biotechnology. 2007;23(2):257-61. 
68. Bakar MFA, Karim FA, Perisamy E. Comparison of Phytochemicals and Antioxidant Properties of Different Fruit Parts of Selected Artocarpus Species from Sabah, Malaysia. Vol. 44, Sains Malaysiana. 2015.

69. Gopinathan M, Yusof YA, Pui LP. Effects of different drying methods on the physicochemical and antioxidant content of "cempedak" (Artocarpus Integer L.) powder. Journal of Food Processing and Preservation. 2020 Dec 1;44(12):e14966.

70. Ee GCL, Teo SH, Go R, Lim CK, Lm YM, Bong CFJ. Free Radical Scavenging Effect of Artocarpus kemando and Artocarpus odoratissimus: Structure-Activity Relationship of Flavonoid Derivatives. Asian Journal of Chemistry. 2012;24(1):231-4.

71. Abu Bakar MF, Mohamed M, Rahmat A, Fry J. Phytochemicals and antioxidant activity of different parts of bambangan (Mangifera pajang) and tarap (Artocarpus odoratissimus). Food Chemistry. 2009 Mar 15;113(2):479-83.

72. Moke LE, Ngbolua K, Bongo GN, Messi LM, Noté OP, Mbing JN, et al. Artocarpus heterophyllus Lam. (Moraceae): Phytochemistry, Pharmacology and Future Directions, a minireview. Journal of Advanced Botany and Zoology. 2017;5(3):1-8.

(C) 2021 by the authors. Submitted for possible open access publication under the terms and conditions of the Creative Commons Attribution (CC BY) license (http://creativecommons.org/licenses/by/4.0/). 